Al-Masāq

Journal of the Medieval Mediterranean

\title{
"Going to the Extremes": The Balearics and Cyprus in the Early Medieval Byzantine Insular System
}

\section{Luca Zavagno}

To cite this article: Luca Zavagno (2019) "Going to the Extremes": The Balearics and Cyprus in the Early Medieval Byzantine Insular System, Al-Masāq, 31:2, 140-157, DOI: 10.1080/09503110.2019.1602375

To link to this article: https://doi.org/10.1080/09503110.2019.1602375

曲 Published online: 26 Apr 2019.

Submit your article to this journal $₫$

Lll Article views: 103

Q View related articles ๘

View Crossmark data 


\title{
"Going to the Extremes": The Balearics and Cyprus in the Early Medieval Byzantine Insular System
}

\author{
Luca Zavagno
}

\begin{abstract}
This contribution mainly focuses on Cyprus and the Balearics, islands located at opposite geographical extremes of the Byzantine Mediterranean, during the passage from Late Antiquity to the early Middle Ages. Historians have often regarded these islands as peripheral additions to the Byzantine heartland of the Aegean and the Anatolian plateau; this article argues that, in fact, archaeological and material indicators (such as ceramics, lead seals and coins), paired with the scarce textual sources, point to a certain degree of economic prosperity in the abovementioned islands during the period under scrutiny, suggesting that they continued to play an important role in the political, administrative and religious structures of the Byzantine Empire. A resilient insular economy and continuity of local production of artefacts was ensured by the persistence of demand from local secular and religious elites and regular, if infrequent, contacts with other areas of the Byzantine heartland or the Muslim Mediterranean.
\end{abstract}

\section{ARTICLE HISTORY}

Received 11 July 2018

Accepted 18 January 2019

\section{KEYWORDS}

Cyprus; Balearics; Frontier; Islands; Mallorca; Byzantium

The chronicle attributed to Patriarch Sebeos was written at a time when the dust of the Islamic conquest was settling across the former eastern provinces of the Byzantine Empire. ${ }^{1}$ Although the chronicle originated in Armenia and was mainly focused on the life of the Shahanshah of Persia, Khusro II (r. 590-628), it also contains significant and important references to the reigns of the Byzantine emperors Heraclius (r. 610-641) and Constans II (r. 642-664). Among these we find the following transient episode:

The son of the emperor Heraclius [...] joined Theodore, the nephew of Heraclius called Magistros, and many of the magnates of the city and Vahan Khorkhoruni. They all conspired to kill Heraclius and set his son Athalarikos on the throne of the kingdom. [...] The details of the plot were conveyed in full to the ear of the king by a certain curator. [He then] ordered that the next morning his son and nephew and all their fellow-conspirators be arrested and the nose and right hand of them all be cut off. ${ }^{2}$

Conspiracies were a common occurrence in the Byzantine court; only a few Byzantine emperors died in their bed. This one would have remained a footnote in the history of Heraclius's long reign, but for the Short History of Patriarch Nikephoros (r. 806-815). ${ }^{3}$ This text is one of the most important sources for the period known as "iconomachy",

CONTACT Luca Zavagno luca.zavagno@bilkent.tr Department of History, University of Bilkent, Ankara, Turkey

${ }^{1}$ Sebeos, History, trans. Robert Thomson and James Howard-Johnston, The Armenian History Attributed to Sebeos [Translated Texts for Historians, volume XXXI], volumes I-II (Liverpool: Liverpool University Press, 1999), I: xii-xiv.

${ }^{2}$ lbid., I: 92-3.

${ }^{3}$ Walter E. Kaegi, Byzantium and the Early Islamic Conquests (Cambridge: Cambridge University Press, 1968), pp. 190, 261. (C) 2019 Society for the Medieval Mediterranean 
as Nikephoros was an imperial secretary under Leo IV (r. 775-780), and was later elevated to the patriarchal throne by Emperor Nikephoros I (802-811). ${ }^{4}$ In a passage of his Short History, Patriarch Nikephoros also wrote about the rebellion of Athalaric and Theodore against Heraclius, adding an interesting detail. The first round of mutilation was not regarded as sufficient punishment, for the Short History mentions that Athalaric was exiled to one of the Prinkipos islands off the coast of Constantinople, while Theodore was instead sent to Gaudemelete (modern Gozo in the Maltese Archipelago) with instructions for the local governor to cut off one of his legs upon arrival. ${ }^{5}$

That islands occur in Byzantine literary sources as places of exile should come as no surprise: Bishop Victor of Tunnuna (d. 570), a supporter of proscribed theological tracts the Three Chapters, lamented his exile to the Balearics in the first decade of the sixth century. ${ }^{6}$ Although a man of God might have regarded an island as the ideal place to indulge in prayer and meditation, the isolation a small island enforced seems to have been unbearable even for saints. The Life of Euthymios of Sardis, written in the first half of the ninth century, reports that the holy man grieved during the time he spent on the island of Pantelleria, an islet off the southern Sicilian coast, although he was accompanied by two other bishops. ${ }^{7}$ Here one should acknowledge that those lamenting and ranting against the unbearable isolation of life on an island were often deliberately indulging in a literary topos. As Burgarella and Cosentino have cogently remarked, one should always keep in mind the two opposite attitudes that Greek and Roman culture had towards islands as these trickled down into Byzantine literature. ${ }^{8}$ One the one hand, islands evoked remoteness and marginality, which were sometimes positively identified with mythical and semi-utopian spaces (like the Islands of the Blessed). On the other, they played an essential role in terms of trade and connectivity, for "in ancient and medieval seafaring orientation and following the right course were facilitated by the observation of visible points". 9

In other words, it seems that prevailing cultural attitudes encapsulated islands de facto in a geography of opposites - static/dynamic, isolated/connected, conservative/open which hampers any attempt to propose a definition of an island within Byzantine culture. There is no space here to address the origins of these prejudices towards islands, which partially stemmed from their intrinsic relationship with the sea, itself regarded as an untrustworthy friend that could bring life and connect peoples but could

\footnotetext{
${ }^{4}$ Leslie Brubaker, Inventing Byzantine Iconoclasm (London: Bloomsbury, 2012), pp. 81-2.

${ }^{5}$ Nikephoros, Nikephoros Patriarch of Constantinople: Short History. Text, Translation and Commentary, ed. and trans. Cyril Mango [Dumbarton Oaks Texts, volume X] (Washington DC: Dumbarton Oaks Museum and Collection, 1990), p. 73.

${ }^{6}$ Vittore di Tunnna, Chronica: Chiesa e Impero nell'età di Giustiniano, ed. Antonio Placanica [Per verba, volume IV] (Firenze: SISMEL Edizioni del Galluzzo, 1997), p. 27; See also Conquerors and Chroniclers of Early Medieval Spain, trans. Kenneth Baxter Wolf, $2^{\text {nd }}$ edn [Translated Texts for Historians, volume IX] (Liverpool: Liverpool University Press, 1990), p. 5; Margarita Vallejo Girvés, Hispania y Bizancio: Una relación desconocida (Madrid: Ediciones Akal, 2012), pp. 450-1.

${ }^{7}$ Methodios, Life of Euthymios of Sardis, trans. Jean Gouillard, "La vie d'Euthyme de Sardes", Travaux du Centre de Recherche d'Histoire et de Civilisation de Byzance 10 (1987): 36-46.

${ }^{8}$ Filippo Burgarella, "Bisanzio e le Isole", in Forme e caratteri della presenza bizantina nel Mediterraneo occidentale: la Sardegna (secoli VI-XI), ed. Paola Corrias (Cagliari: Condaeghes, 2012), pp. 33-42; Salvatore Cosentino, "Mentality , Technology and Commerce: Shipping amongst the Mediterranean Islands in Late Antiquity and Beyond", in The Insular System of the Early Byzantine Mediterranean, ed. Demetrios Michaelides, Philippe Pergola and Enrico Zanini [British Archaeological Reports, International Series, volume MMDXXIII] (Oxford: Archaeopress, 2013), pp. 65-70; idem, "A Longer Antiquity? Cyprus, Insularity and the Economic Transition", Cahiers du Centre d'Études Chypriotes 43 (2012): 93-102, pp. 93-7.

${ }^{9}$ Ibid., 93.
} 
transform into a mortal danger to ships and seafarers. One could also think here of the Biblical reflections of this attitude or the terrestrial character of aristocratic Byzantine culture (as inherited from the Romans), which had always looked down on the maritime life, since elites had always been economically dependent on the land. ${ }^{10}$ The world of seafaring, inevitably linked to trade and technological innovation, was a stranger to the cultural conservatism of the Byzantine elites.

This complex and contradictory Classical, and later Byzantine, literary and documentary representation of islands has often been uncritically adopted in Byzantine historiography. Indeed, Byzantine historiography has generally not devoted much attention to islands at all: they have been noticeably absent from almost all the most recent general works focused on the "Byzantine millennium", underscoring their apparent marginality. For instance, the Oxford Dictionary of Byzantium has no entry dedicated to the concept of islands or insularity. ${ }^{11}$ Islands have thus been regarded by Byzantine historians and archaeologists as peripheral to the political, social and economic changes that the Byzantine Empire experienced, partly because they are so treated by surviving literary sources and partly because little effort has been made to recover an alternative narrative using other approaches. With respect to the transformation that the Byzantine Empire experienced from the mid-seventh century, however, several islands can be identified as key territorial units, competed over fiercely until they were recaptured by the expanding empire in the tenth century (Crete and Cyprus) or were lost forever (Sardinia and the Balearics). ${ }^{12}$ Their absence from analyses of the period, therefore, provides a valuable opportunity for re-thinking the island perspective.

The only real escapees from this largely island-free interpretative framework of Byzantine history have been Sicily and the Aegean islands. The latter have been regarded as part and parcel of the Byzantine heartland, a label famously created by Wickham for the two wildly different but constitutive geographical pillars of the Empire during the passage from Late Antiquity to the early Middle Ages, the Anatolian plateau and the Aegean. ${ }^{13}$ The former, Sicily, retained its importance in imperial sources and subsequent historiography as one of the main suppliers of grain to the capital after the breaking of the Egyptian tax spine in 642. In this respect, it is no surprise that Sicily was at the heart of imperial interests, as shown by Emperor Constans II, who according to Theophanes, "abandoned Constantinople and moved to Syracuse, intending to transfer the capital to Rome". ${ }^{14}$ Although the Emperor met his fate in a bathtub in the Sicilian capital not long afterwards, the victim of a grisly murder and a short-lived coup, one can indeed conclude with Cosentino that, "[Constans's] decision of settling in Syracuse may have been determined not only by the strategic position of the island in the Mediterranean, but above all by the vitality of its

\footnotetext{
${ }^{10}$ Antonio Carile, "La talassocrazia romea, VI-VIII sec.", in Storia della marineria bizantina, ed. Antonio Carile and Salvatore Cosentino (Bologna: Lo scarabeo, 2004), pp. 7-32, esp. 7-9.

${ }^{11}$ The Oxford Dictionary of Byzantium, ed. Alexander Kazhdan, volumes I-III (Oxford: Oxford University Press, 1991).

${ }^{12}$ See for instance J. Haldon, The Palgrave Atlas of Byzantine History (New York: Palgrave Macmillan, 2005), pp. 58-63, 68-76; Michael Decker, The Byzantine Dark Ages (London: Duckworth, 2016), pp. 138-41; Elizabeth Jeffreys, John Haldon and Robin Cormack, The Oxford Handbook of Byzantine Studies (Oxford: Oxford University Press, 2008); Liz James, A Companion to Byzantium (Oxford: Wiley-Blackwell, 2008). The last two seminal works include no specific contribution on the theme of islands or insularity.

${ }^{13}$ Chris Wickham, Framing the Early Middle Ages: Europe and the Mediterranean 400-800 (Oxford: Oxford University Press, 2005), pp. 29-37.

${ }^{14}$ Theophanes, The Chronicle of Theophanes the Confessor: Byzantine and Near East History, A.D. 284-813, ed. and trans. Cyril Mango and Roger Scott (Oxford: Clarendon Press, 1997), p. 486. See also Haldon, Palgrave Atlas, 57.
} 
economy". ${ }^{15}$ Likewise, the island was later (around 700) turned into a theme, with its strategos residing in Syracuse, where a mint remained operative until the fall of the island into Aghlabid hands in the late ninth century, testifying to its ongoing economic prosperity. ${ }^{16}$ Thus, Sicily has often been regarded as the last western outpost of the Byzantine Empire. This has given it a somewhat Janus-faced role historiographically, attached on one side to the above-mentioned Byzantine Aegean heartland, and on the other paired with Crete and Cyprus in the eastern Mediterranean, labelled all three as liminal spaces, mainly performing the function of military strongholds on a frontier between two irreconcilable or conflicting worlds (Muslim vs. Christian, caliphate vs. empire). ${ }^{17}$

I return to Sicily and to the supposed role that islands played along the medieval political and religious division of the Mediterranean shortly, but here I want to stress the importance of leaving behind intellectual speculation and tropes (often deriving from the Byzantine literary sources) and moving towards everyday practices in order to highlight real aspects of insularity. Archaeology and material culture provide new avenues by which to explore the role islands played within the mechanisms of production and distribution that shaped the Late Antique and early medieval world. In this way, one can move away from the image of insular spaces as drawn by Byzantine chroniclers and hagiographers alike, as remote areas belonging to the frontier of the Empire. The fruitfulness of this approach can be seen in the recent reassessment of the importance of Cyprus as a supposed bulwark of Byzantine iconophiles, the only place where "iconoduly" could be professed, since the island was distant from the persecutory grip of the iconoclastic Constantinopolitan emperors. This interpretation has recurred in many works relating to the history of the island, de facto contributing to the myth of Cyprus as a semi-independent iconophile safe-haven under the spiritual and political guidance of the local autocephalic archbishop. ${ }^{18}$ Unfortunately, and as recent reassessment particularly of architectural and visual evidence has demonstrated, such a characterisation has been based upon an uncritical assessment of particular literary sources, such as the eighthcentury Life of Saint Stephen the Younger, which has been deconstructed and labelled as largely fictional. ${ }^{19}$ That a re-evaluation has been such a long time coming may be due to a large extent to the fact that a specific narrative of a semi-independent and staunchly Orthodox Cyprus, which has suited local needs, overlapped closely with the preconceived idea of the remoteness of islands, making traditional conclusions seem a priori plausible, even in the face of challenges from material culture and archaeology. ${ }^{20}$

\footnotetext{
${ }^{15}$ Salvatore Cosentino, "Constans II and the Byzantine Navy", Byzantinische Zeitschrift 100 (2007): 577-603, p. 594, though it is worth noting that, according to Theophanes as cited above, the long-term plan was to move to the mainland and Rome, rather than to remain on an island.

${ }^{16}$ Cécile Morrisson, "La Sicile byzantine: Une lueur dans les siècles obscurs", Quaderni Ticinesi di Numismatica e Antichità Classica 27 (1998): 307-34.

${ }^{17}$ Angeliki E. Laiou and Cécile Morrisson, The Byzantine Economy (Cambridge: Cambridge University Press, 2007), p. 43; John F. Haldon, The Empire That Would Not Die: The Paradox of Eastern Roman Survival, 640-740 (Cambridge: Cambridge University Press, 2016), pp. 33-56; Telemachos C. Lounghis, Byzantium in the Eastern Mediterranean: Safeguarding East Roman Identity (407-1204) [Texts and Studies of the History of Cyprus, volume LXIII] (Nicosia: Cyprus Research Center, 2010), pp. 20-35.

${ }^{18}$ See on this Luca Zavagno, Cyprus between Late Antiquity and the Early Middle Ages (ca. 600-800): An Island in Transition (London: Routledge, 2017), pp. 53-5.

${ }^{19}$ Leslie Brubaker and John Haldon, Byzantium in the Iconoclast Era (c. 680-850): The Sources. An Annotated Survey [Birmingham Byzantine Studies and Monographs, volume VII] (Aldershot: Ashgate, 2001), pp. 234-47.

${ }^{20}$ D.M. Metcalf, Byzantine Cyprus, 491-1191 [Texts and Studies of the History of Cyprus, volume LXII] (Nicosia: Cyprus Research Center, 2009), pp. 1-19.
} 
A similar example can be offered by the island of Malta. Archaeology, as well as numismatic and sigillographic evidence, has demonstrated that from the mid-seventh century the Maltese archipelago was not simply a distant outpost on the imperial frontier. Rather, it showed a "degree of autonomous action in communal terms, managing to economically bridge the political divide existing between the Byzantines and the Arabs". ${ }^{21}$ The best example of this peculiar role comes in the form of the eighth- or ninth-century seal of Niketas, archon kai drouggarios of Malta, which was not found on the archipelago or in a nearby region under Byzantine control but, rather surprisingly, in Tunisia. This is tantalising evidence of political contacts across the supposed north-south Mediterranean divide as well as of the active role of insular authorities in maintaining open political channels with the Arabs. ${ }^{22}$

Archaeology and material evidence lies at the very heart of my analytical approach to the fate and historical development of large Byzantine islands presented here, and a few preliminary caveats are needed. The first has to do with the interpretative framework proposed in the only existing systematic account of the Byzantine insular world, Elizabeth Malamut's 1988 work, Les Iles de l'Empire Byzantine, VIIIème-XIIème siècle. Malamut distinguishes between the western and eastern Mediterranean basin, and, except for Sicily, she considers the former to be beyond the political and administrative reach of Constantinople. $^{23}$ The latter, meanwhile, included islands which were too unimportant and close to the continent to have any real political or economic role in the historical trajectories of the Constantinopolitan empire. Cyprus and Crete, however, remained the exception to this rule owing to their strategic relevance along the frontier with the Muslim world. Malamut's interpretation has therefore led some scholars to dwell on the idea of islands as simply a maritime continuation of the Arab-Byzantine frontier for the eastern and western basin of the "Great Sea". ${ }^{24}$

Instead, I advocate for a reassessment of the concept of periphericity, by examination of the Byzantine insular world, in light of the fact that the Byzantine navy continued to play an important role in both the western and the eastern basins of the Mediterranean, where the creation of the Karabisianoi squadron and later the Kybirraiothai theme (732), "provided the Byzantine fleet with a peculiar organization and new strategic functions which stemmed from the new Arab threats [in the area]" ${ }^{25}$ Regional fleet-squadrons based in Sicily and Sardinia patrolled the Tyrrhenian Sea and repeatedly confronted Arab pirates in the period under scrutiny. One could mention, for instance, the considerable force of 300 dromones that wrestled Pantelleria and Lampedusa back from the Arabs in $760 .^{26}$

\footnotetext{
${ }^{21}$ Brunella Bruno and Nathaniel Cutajar, "Imported Amphorae as Indicators of Economic Activity in Early Medieval Malta", in The Insular System of the Early Byzantine Mediterranean, ed. Demetrios Michaelides, Philippe Pergola and Enrico Zanini [British Archaeological Reports, International Series, volume MMDXXIII] (Oxford: Archaeopress, 2013), pp. 15-30, 28.

${ }^{22}$ Gustave Léon Schlumberger, "Sceaux byzantins inédits (quatrième série)", Revue d'Études Grecques 13 (1900): 467-92, p. 492 n. 203.

${ }^{23}$ Elizabeth Malamut, Les îles de I'Empire byzantin. VIIle-XIle siècles, 2 vols. (Paris: Sorbonne, 1988).

${ }^{24}$ Lounghis, Byzantium in the Eastern Mediterranean.

${ }^{25}$ Salvatore Cosentino, "Un epitafio sardo del secolo VI concernente probabilmente un dromonarius", in Storia della marineria bizantina, ed. Antonio Carile and Salvatore Cosentino (Bologna: Lo scarabeo, 2004), pp. 185-208, esp. 207. See also Elizabeth Jeffreys and John Pryor, The Age of the $\Delta \rho \circ \mu \omega v$ : The Byzantine Navy ca. 500-1204 [The Medieval Mediterranean, volume LXII] (Leiden: Brill, 2006), pp. 32-5; and Constantin Zuckerman, "Learning from the Enemy and More: Studies in 'Dark Centuries' Byzantium", Millennium-Jahrbuch 2 (2005): 79-136.

${ }^{26}$ Codex Carolinus, ed. W. Gundlach, in Epistolae Merowingici et Karolini aevi (I), ed. E. Dümmler, W. Gundlach, W. Arndt and C. Rodenberg [Monumenta Germaniae Historica, Epistolae in quarto, volume III] (Berlin: Weidmann, 1892), pp. 459-657, esp. 514-15. See also Carile, "Talassocrazia", 25. On the presence and interventions of the Byzantine fleet in the
} 
The importance of the navy should be paired with the economic resilience islands boasted well into the ninth century. This has led in turn to a new interpretation, proposed by Zanini and others, who have argued that Sicily and Cyprus (and to a lesser extent Crete, Malta, Sardinia and the Balearics) acted as a third political and economic pole, between the Anatolian plateau and the Aegean Sea, in the Byzantine Mediterranean. ${ }^{27}$

As will be seen, I find this latter interpretation a more fruitful starting point, but propose a refinement by highlighting the geo-strategic, political and cultural peculiarities of each of these islands. For instance, Cyprus and the Balearics, lying at the extremes of the Byzantine Mediterranean, seem to have been more influenced, in contrast to other islands, by, respectively, the gravitational pull of the Umayyad (and later 'Abbāsid) caliphate and by the Andalusī emirate, developing along peculiar socio-economic, cultural and political lines that cannot be documented in Sicily or Crete (and only partially in Sardinia). Here I am perfectly aware that the Balearics should be handled with more geo-political care than Cyprus; this because the Balearics are a composite archipelago boasting two pairs of islands separated by a rather large stretch of sea (ca. $130 \mathrm{~km}$.). The first pair is composed of the island of Mallorca (the biggest of the entire archipelago with the small islet of Cabrera to the south) and Menorca; the second pair - called Pityusic islands - comprises Ibiza and Formentera. ${ }^{28}$ The latter actually lie closer to the Spanish coast (Denia) than to Mallorca. Regional differences are therefore important within the Balearic archipelago, although there is no evidence to support a possible stronger political and cultural influence over the Pityusics on the part of the polities (Visigoths, Vandals and Byzantines, and later Carolingians and Umayyads) that dominated the Iberian Peninsula over the centuries.

It is rather conspicuous, however, that the abovementioned pull is more visible in Cyprus, for which we possess both limited literary and documentary sources and good archaeology. ${ }^{29}$ Indeed, for the Balearics the situation is rather different, as almost no archaeological findings have appeared for the period under scrutiny. Like Cyprus, the Balearic archipelago indeed boasts a multitude of early Christian basilicas, as documented in Ibiza, Mallorca and Menorca, and these basilicas seem to have played a similarly agglutinative role in the settlement pattern of both the Cypriot and the Balearic countryside in the passage from Late Antiquity to the early Middle Ages. ${ }^{30}$ Indeed, material culture and archaeology have demonstrated that some of these basilicas remained the focus of diminished but still vital rural settlements well into the eighth century, as seen in the case of Son Fadrinet and Saint Lluís in Menorca and Agia Varvara and Agias Trias in Cyprus. ${ }^{31}$ "Although [in general] the reduction of site numbers is clear, the settlement patterns do

Tyrrhenian well into the ninth century, see also Christophe Picard, La mer des califes: Une histoire de la Méditerranée musulmane, VIle-XIle siècle (Paris: Du Seuil, 2015), pp. 298-302; Jeffreys and Pryor, Age of the $\Delta \rho{ }^{\prime} \mu \omega v, 41$.

${ }^{27}$ Enrico Zanini, "Introduzione: Le ragioni di un seminario, le ragioni di un libro", in The Insular System of the Early Byzantine Mediterranean, ed. Demetrios Michaelides, Philippe Pergola and Enrico Zanini [British Archaeological Reports, International Series, volume MMDXXIII] (Oxford: Archaeopress, 2013), pp. 1-6.

${ }^{28}$ Josep Amengual, "The Origin and Timespan of the Archipelagos' Names, the Islands and the Cities of the Balearic and Pitiusan Islands", in Insular identity and Epigraphy in the Roman World, ed. Javier Velaza (Cambridge: Cambridge Scholars, 2017), pp. 197-221.

${ }^{29}$ Zavagno, Cyprus, 29-62.

${ }^{30}$ Luca Zavagno and Bülent Kizidulman, "A Countryside in Transition: The Galinoporni-Kaleburnu (Cyprus) in the Passage from Late Antiquity to the Early Middle Ages (ca. 600-ca. 850)", Pamákty Archeologické 109 (2018): pp. 233-251.

${ }^{31}$ Ibid., 243-4. On Saint Lluís, see Juan Mascarò, "Arqueologia romana del territory de Sant Lluís (Menorca)", Arqueomenorca Monografies, ed. J. C. De Nicolás Mascaró 36, (2018): pp. 1-43. 
not seem profoundly modified [in particular] there is no evidence of an extensive flight to the hills". ${ }^{32}$ I shall return to this point and to the related problem of the "castralization" of the insular settlement pattern below.

Indeed, in order to understand the exceptionality of the Balearics and Cyprus, one must first address commonalities and try to document some traits that all insular spaces had in common, and which together constitute a new definition of Byzantine insularity capable of providing a firm basis for future micro-regional studies. Two such insular qualities will be examined in detail here. ${ }^{33}$

The first concerns the economic role insular spaces played during the fragmentation and localisation of a formerly unified Mediterranean exchange system from the late sixth/early seventh century onwards. The economic importance of insular spaces in a unified Roman Mediterranean was subsumed as trans-regional shipping routes became less frequented and the "Mediterranean mondo" broke up. ${ }^{34}$ "A world system that had been fairly stable in 600 , without being tied too extensively to single routes or commodities, disappeared in one century, even though most of the regions which had comprised it did not themselves become substantially poorer". ${ }^{35}$ The large Mediterranean islands ostensibly suffered less - at least until Sicily and Crete fell into the hands of the Aghlabids and the Andalusian pirates in the first decades of the ninth century. ${ }^{36}$

This picture has been enhanced by recent refinements in the analysis of ceramics as guide fossils from the period, in particular globular amphorae (produced in the Mediterranean between the seventh and ninth centuries) as well as local wheel-made painted wares as yielded in Crete, Sardinia and Cyprus, and on coastal Lycian sites like Balboura or in the Adriatic lagoon-hub of Comacchio. ${ }^{37}$ These all point to the resilience of seventhto-ninth-century local and regional networks of production and distribution as well as intra-regional exchange, which did not stem exclusively from the needs of the fiscal system. ${ }^{38}$ In other words, as Cosentino has shown, "throughout the seventh and eighth century islands seem to remain an economic space relatively more developed than northern and central Italy, the Balkans or Asia Minor". ${ }^{39}$ Numismatic, sigillographic and ceramic evidence, as well as archaeology, points to a more resilient insular economic world than the other regions of the Byzantine heartland, at least until the very beginning of the ninth century. ${ }^{40}$ In this light, it is important to stress that an analysis of the economic trajectories of the large islands of the Byzantine Mediterranean allows us to partially pierce the "barrier" between Late Antiquity and the early Middle Ages, famously defined

\footnotetext{
${ }^{32}$ Catalina Mas Florit and Miguel Cau Ontiveros, "From Roman to Byzantine: The Rural Occupation of Eastern Mallorca (Balearic Islands)", Journal of Mediterranean Archaeology 24/2 (2011): 191-217, p. 211.

${ }^{33}$ See also Luca Zavagno, "Islands: Not the Last Frontier: Insular Model in Early Medieval Byzantine Mediterranean, c. 650-c. 850", in Borders and Conflicts in the Mediterranean Basin, ed. Giuseppe D'Angelo and Jorge Martins Ribeiro [Mediterranean, Knowledge, Culture and Heritage, volume II] (Fisciano: ICSR Mediterranean Knowledge, 2016), pp. 37-50.

${ }^{34}$ Michael McCormick, The Origins of the European Economy: Communications and Commerce AD 300-900 (Cambridge: Cambridge University Press, 2001).

${ }^{35}$ Wickham, Framing, 717.

${ }^{36}$ Cosentino, "Mentality", 77.

${ }^{37}$ Joanita Vroom, "From One Coast to Another: Early Medieval Ceramics in the Southern Adriatic Region", in From one Sea to Another: Trading Places in the European and Mediterranean Early Middle Ages. Proceedings of the International Conference, Comacchio 27th-29th March 2009, ed. S. Gelichi and R. Hodges (Turnhout: Brepols, 2012), pp. 353-392.

${ }^{38}$ Wickham, Framing, 718.

${ }^{39}$ Cosentino, "Mentality", 73.

${ }^{40} \mathrm{lbid}$.
} 
by Wickham as the gap between two prosperous "trade cycles". ${ }^{11}$ Therefore, though acknowledging that the economic role of islands was not the same in the sixth century as in the eighth and ninth, this article will show that some "peripheral" insular economic spaces - like the Balearics and Cyprus - grafted their resilience onto the political and military struggle between Mediterranean polities. This is not to imply that wars or pirate raids did not sometimes wreak havoc on their economic and social life, but rather to object to the idea that these violent episodes brought about the economic impoverishment, urban collapse, and administrative marginalisation of these islands. In fact, their geo-strategic importance and the role they played across regional, if not trans-Mediterranean shipping routes, was partially enhanced by the fluidity of the political Mediterranean game. The Frankish relationship with the eighth-century Balearics or the coexistence of Byzantine and Muslim currency in both Cyprus and the Balearics come to mind as examples of this phenomenon. ${ }^{42}$

The second quality explored here hinges on the abovementioned economic resilience and relates to the peculiar rules of the insular religious and political game played by local ecclesiastical and administrative elites, as Constantinople remained vigilant and interested in the political and religious affairs of the islands, while still allowing considerable scope for local latitude. The presence of Constantinopolitan administrative and military (naval) machinery has been shown already in the case of Malta and Lampedusa but it is also true for Sardinia, where the persistence of Byzantine structures of fiscal, military and religious governance was enhanced by the title of archon Sardiniae, which appears in the tenth-century De Caerimoniis Aulae Byzantinae, in eighth- to ninth-century Byzantine lead seals in Latin and Greek, and in sixth- to tenth-century religious buildings dedicated to Byzantine military saints that dot the rural Sardinian landscape. ${ }^{43}$ Some of these churches boasted celebratory inscriptions (dated to the late ninth or tenth century), using high-tone Greek and related to local aristocratic families actively sponsoring the (re)construction or refurbishment of ecclesiastical buildings. It is clear that these families were on the lookout for ideological and political legitimacy stemming from Constantinopolitan socio-cultural models, as also documented in Crete and Sicily. ${ }^{44}$

Nevertheless, we should not forget the socio-cultural and political flexibility shown by the local insular ruling class - a ruling class characterised essentially by the possession (at different and various levels) of locally-entrenched social and economic power and the capacity to navigate through the ebbs and flows of eastern Mediterranean politics. ${ }^{45}$ As repeatedly mentioned, Sicily was the exception to the rule here due to its economic importance as grain supplier for the capital, mirrored politically by its thematic administrative

\footnotetext{
${ }^{41}$ Chris Wickham, "The Mediterranean around 800: On the Brink of the Second Trade Cycle", Dumbarton Oaks Papers 58 (2004): 161-74.

${ }^{42}$ For the Balearics, see Josep Amengual, "Vbi pars graecorum est: medio milenio de historia relegada de las Baleares y las Pitiusas", Pyrenae 36/2 (2005): 87-113; for Cyprus, see Luca Zavagno, "'Betwixt the Greeks and the Saracens': Coins and Coinage in Cyprus in the Seventh and Eighth Centuries", Byzantion 81 (2011): 448-93.

${ }^{43}$ See Salvatore Cosentino, "Potere e istituzioni nella Sardegna bizantina", in Ai confini dell'impero: Storia, arte e archeologia della Sardegna bizantina, ed. Paola Corrias and Salvatore Cosentino (Cagliari: M\&T Sardegna, 2002), pp. 1-13, for a detailed inventory of the literary and material evidence mentioned here.

${ }^{44}$ Annliese Nef and Vivien Prigent, "Per una nuova storia dell'alto medioevo siciliano", Storica 12/35-6 (2006): 1-55, pp. 35-6.

${ }^{45}$ Enrico Zanini, "Archeologia dello status sociale nell'Italia bizantina: Tracce, segni e modelli interpretativi", in Archeologia e società tra Tardo Antico e Alto Medioevo, ed. Gianpetro Brogiolo and Alexandra Chavarría Arnau [Documenti di archeologia, volume XLIV] (Padova: SAP, 2007), pp. 17-41, esp. 27.
} 
status. The significance of Sicily and the prominent role it played in Byzantine military, naval and political strategies is demonstrated by material indicators such as ceramics, which point to an island roughly divided into western and eastern halves, as can be seen from the analysis of globular amphorae. As Vaccaro puts it, "the circulation of these [ceramic] types links a series of sites in the central and southern Tyrrhenian Sea including those in north-western Sicily, the bay of Naples, Rome, Ostia, Portus and Cagliari where the Church of Rome has substantial landholdings" ${ }^{46}$ On the other hand, eastern Sicily was more linked to the Aegean (Crete) and Constantinople via the "ancient trunk route" as identified by McCormick. ${ }^{47}$

While the enduring pull of Sicily at the heart of the Tyrrhenian regional exchange system, lost to Byzantium only in the ninth century, could explain why Sardinia (and possibly Malta and Lampedusa) remained at the heart of imperial interests, the same could not be concluded for the Balearics or Cyprus, located at the opposite extremes of the Byzantine Mediterranean. Here, the fluidity of socio-political and cultural processes can be witnessed beyond the obvious military and diplomatic interactions between Damascus (or Córdoba) and Constantinople that were funnelled through these islands, as local aristocrats and traders bear witness to the formation and existence of "third spaces of hybridity, that is of areas of transition between cultural areas". ${ }^{48}$ In this light, Vionis perspicaciously remarks that islands often became a zone of cross-imperial interaction rather than a cultural barrier between antagonistic empires. ${ }^{49}$

It seems that, on these islands, a resilient post-Roman economy became the foundation for a definition of political status that was unique in the wider Mediterranean context. According to the Arab sources, Cyprus and the Balearics were the land(s) of the truce (dār al-'ahd), poised between the regions under the direct control of the Caliphate and those recognising Byzantine sovereignty. According to Arab juridical exegesis, the pact in question was a form of nominal truce signed by three parties: the Muslims, the local inhabitants, who retained a degree of independence as a third party, and the Byzantine authorities. ${ }^{50}$

An attentive examination of the early Islamic legal and historiographical evidence has pointed to the intricate nexus of socio-political, cultural and economic relationships that lay at the heart of these truce-agreements. ${ }^{51}$ They remained peculiar to territories regarded by the Arabs as "unlike any others as [their] status, location and shared influence

\footnotetext{
${ }^{46}$ Emanuele Vaccaro, "Sicily in the Eighth and Ninth Centuries AD: A Case of Persisting Economic Complexity?", Al-Masāq 25/ 1 (2013): 34-60, pp. 57-60.

${ }^{47}$ Alessandra Molinari, "Sicily between the 5th and the 10th Century: Villae, villages, towns and beyond. Stability, expansion or recession?", The Insular System of the Early Byzantine Mediterranean, ed. Demetrios Michaelides, Philippe Pergola and Enrico Zanini [British Archaeological Reports, International Series, volume MMDXXIII] (Oxford: Archaeopress, 2013), pp. 97-114; Vaccaro, "Sicily", 58-9; McCormick, Origins of the European Economy, 501-3.

${ }^{48}$ Daniel König, Yassir Benhima, Rania Abdellatif and Elisabeth Ruchaud, "Les acteurs des transferts culturels : Introduction à la thématique", in Acteurs des transferts culturels en Méditerranée médiévale, ed. Rania Abdellatif, Yassir Benhima, Daniel König and Elisabeth Ruchaud [Ateliers des Deutschen Historischen Instituts Paris, volume IX] (München: Oldenbourg, 2012), pp. 9-19, esp. 16.

${ }^{49}$ Athanasios Vionis, "Reading Art and Material Culture: Greeks, Slavs and Arabs in the Byzantine Aegean", in Negotiating CoExistence: Communities, Culture and Convivencia in Byzantine Society, ed. Barbara Crostini and Stefano La Porta (Trier: Wissenschaftlicher Verlag Trier, 2013), p. 127.

${ }^{50} J u a n$ Signes Codoñer, "Bizancio y les islas Baleares en los siglos VIII y IX", in Mallorca y Bizancio, ed. Robert Durán Tapia (Palma de Mallorca: Asociación Amigos del Castillo de San Carlos "Aula General Weyler", 2005), pp. 45-99, esp. 46-7; also Miguel Cau Ontiveros and Catalina Mas Florit, "The Early Byzantine Period in the Balearic Islands", in The Insular System of the Early Byzantine Mediterranean, ed. Demetrios Michaelides, Philippe Pergola and Enrico Zanini [British Archaeological Reports, International Series, volume MMDXXIII] (Oxford: Archaeopress, 2013), pp. 31-45.

${ }^{51}$ Ryan J. Lynch, "Cyprus and Its Legal and Historiographical Significance in Early Islamic History", Journal of the American Oriental Society 136/3 (2016): 535-50.
} 
presented the Muslim jurists and administrators with a number of challenges". 52 The 'ahd did not "simply [concern] two parties that went through constant cycles of warfare, treaty, and the usual seasonal raiding; the case of the Muslims and the Byzantines in Cyprus [and the Balearics] reveals instead the complexity this relationship could take based on perceived need". ${ }^{53}$ In all probability it was left to the local population and elites to navigate through these challenges, creating solutions that allowed daily life and business to continue whenever possible. One indeed wonders if we are in the presence of what Purcell has cogently defined as a threshold, that is, areas where the development of polities derives its character and dynamism from straddling peripheries and from the control of abutting connectivities. ${ }^{54}$

Although islands in general are often (and sometimes stereotypically) regarded as privileged hubs across shipping routes and gateway settlements, I argue that Cyprus and the Balearics may represent rather peculiar examples, for they draw their character from their position at the interface between different systems (Byzantium vs. caliphate/Byzantium vs. emirate). It is indeed in these insular spaces that we also encounter shared fiscal sovereignty, peculiar and ingenious ways to survive the political difficulties of the hour by appealing to a rival polity for military help and, finally, episodes of commercial and political convivencia represented by Umayyad and Byzantine ceramics, coins and seals yielded in the same archaeological contexts. It is to this evidence that I shall now turn.

Here, and as already mentioned, one must admit that in the near-silence of literary sources, better documented and published archaeology and material culture make the "informality" of the rules of the insular political game more noticeable in Cyprus than in the Balearics. This is mainly down to the size of the former island and its proximity to the Umayyad centres of power and the economically lively Syro-Palestinian region, more developed and politically coherent than Spanish al-Andalus in the eighth and ninth centuries. ${ }^{55}$ For Cyprus, I have therefore proposed the model of the "Middle Ground". This model has allowed me to explore the critical role of the island between the seventh and ninth centuries as a point where relations between the Umayyads and Byzantines developed not only in response to external pressures or military conflicts. As one side could not impose full control over the island by ousting the opposition, a peculiar condition emerged hardly found anywhere else in the eastern Mediterranean, in which we can trace the emergence of an elaborate network of social, cultural and economic ties created by two populations living side by side, as shown by ceramic, sigillographic and numismatic evidence. ${ }^{56}$

Hand or wheel-made pottery exported to southern Anatolia and Syria-Palestine presents us with a good parallel to those eighth-century Arab cargo owners who left their inscriptions on some amphorae unearthed in Paphos (where an artisanal and

\footnotetext{
${ }^{52}$ Ibid., 549.

${ }^{53}$ lbid., 550.

${ }^{54}$ Nicholas Purcell, "On the Significance of East and West in Today's 'Hellenistic' History: Reflections on Symmetrical Worlds, Reflecting through World Symmetries", in The Hellenistic West: Rethinking the Ancient Mediterranean, ed. Jonathan William Prag and John Crawley Quinn (Cambridge: Cambridge University Press, 2013), pp. 367-90, esp. 374.

${ }^{55}$ Eduardo Manzano Moreno, "Al-Andalus: Un balance critico", in Histoire et archéologie de l'occident musulman, VIle-XVe siècles: Al-Andalus, Maghreb, Sicile, ed. Philippe Sénac [Méridiennes: Villa, volume IV, Actes du Colloque de Tourtour, Fondation des Treilles, September 2010] (Toulouse: Université de Toulouse-Le Mirail, 2012), pp. 10-17.

${ }^{56}$ Zavagno, Cyprus, 175-6.
} 
domestic quarter with traces of Arab occupation has been unearthed in the area of the harbour). ${ }^{57}$

In Limyra on the Lycian coast, for instance, most of the "dark ages" pottery assemblages have been documented as composed of fine ware and amphorae imported from Cyprus, Egypt and the south-eastern Anatolian coast. ${ }^{58}$ In particular, "some pottery types like Cypriot Red Slip Ware did not disappear after the seventh century as commonly assumed" but remained in use for a longer period". ${ }^{9}$ On the "other" coast of the Mediterranean, "typical eighth-century domestic and cooking wares produced in Cyprus the thin walled, wheel-ridged vessels also known as Dhiorios cooking pots - have been found in Umayyad deposits in Beirut and in eighth-century layers in Palestine" ${ }^{60}$

In a rather similar vein, Byzantine lead seals testify to the presence of high officials and ecclesiastical authorities, whereas those issued by the Caliphal authorities and bearing the peculiar denomination Qubrus could point to original forms of long-term socio-political co-existence. Finally, the local coinage record includes specimens issued by the Constantinopolitan authority as well as late seventh- and early eighth-century Arab-Byzantine coins and post-reform Islamic coins, pointing to a transcultural and transregional acceptance of different monetary units (Byzantine and Umayyad), possibly owing to the peculiar political status of Cyprus as mentioned by Theophanes, who states that in 686-688 the emperor and the caliphs shared the tax revenues of Cyprus, Armenia and Iberia equally. ${ }^{61}$ Moreover, these coins "strongly suggest that Muslim merchants were visiting Cyprus (where early-eighth- to mid-eighth-century post-reform Islamic fulūs make up perhaps 30 or 40 per cent of the eighth-century finds): they hint at trading contacts with Syria-Palestine". ${ }^{62}$

As mentioned above, a treaty similar to the one documented for Cyprus but signed between al-Andalus and Byzantium can be documented for the Balearics, possibly dated to 707 (or later) and renewed in $848 / 9 .^{63}$ The events leading to the renewal are particularly striking as they allow us to draw a comparison with Cyprus. Indeed, two Arabic chroniclers, al-Balādhurī (writing in the early ninth century) and al-Ṭabarī (who wrote his Ta'rikh al-rusul wa-l-mulük in the first two decades of the tenth century) famously mentioned that in 806 Hārūn al-Rashīd (r. 786-809) raided the island of Cyprus because the

\footnotetext{
${ }^{57}$ Vassos Karageorghis and Fredrick Maier, Paphos: History and Archaeology (Nicosia: Leventis, 1984), pp. 292-301; Charles Stewart, "Domes of Heaven: The Domed Basilicas in Cyprus", PhD Thesis, Indiana University, 2008, pp. 73-7; Metcalf, Byzantine Cyprus, 418-23.

${ }^{58}$ Joanita Vroom, "New Light on 'Dark Age' Pottery: A Note on Finds in South-Western Turkey", in Rei Cretariae Romanae Favtorvm. Acta 39. Congressvus Vicesimvs qvartvus rei cretariae romanae favtorvm namvri et dvobvus lovaniis habitvus mmiv (Oxford: Abingdon, 2005), pp. 249-57.

${ }^{59}$ Joanita Vroom, "Limyra in Lycia: Byzantine/Umayyad Pottery Finds from Excavations in the Eastern Part of the City", in Céramiques antiques en Lycie (VIle S. a.C. - VIle S. p.C): Les produits et les marchés (Études 16), ed. Séverine Lemaítre (Bordeaux: Ausonius, 2007), p. 163.

${ }^{60}$ Zavagno, Cyprus, 163.

${ }^{61}$ On the treaty, see Theophanes, Chronicle, 506; for the Arab-Byzantine and Islamic coinage in Cyprus, see Zavagno, "'Betwixt the Greeks and the Saracens"'; Metcalf, Byzantine Cyprus, 482. On the Islamic and Byzantine seals, see D.M. Metcalf, Byzantine Lead Seals from Cyprus [Texts and Studies of the History of Cyprus, volume XLVII] (Nicosia: Cyprus Research Center, 2004), pp. 356-8.

${ }^{62}$ Excavations at the so-called Basilica in Kourion unearthed six post-reform coins, including a gold dinar (dated to 720/1) and silver dirham: see Helen Brown, "Islamic Coins", in Kourion: Excavations in the Episcopal Precinct, ed. Peter Megaw (Washington DC: Dumbarton Oaks Museum and Collection, 2007), pp. 422-3; for the Islamic coins found in Paphos and Saranda Kolones, see D.M. Metcalf, Coinage as Evidence for the Changing Prosperity of Cyprus in Medieval Times [Lectures on the History of Coinage, volume IV] (Nicosia: Cyprus Research Center, 2003).

${ }^{63}$ Signes, "Bizancio et las islas Baleares", 49; cf. Jonathan Jarrett, "Nests of Pirates: The Balearic Islands and La Garde-Freinet Compared", al-Masāq (forthcoming) for a more sceptical treatment of the same evidence.
} 
local inhabitants had broken some clauses of the treaty. ${ }^{64}$ Similarly, the fourteenth-century Moroccan author Abū Ibn Idhārī states that, although the Andalusian coasts were battered by the Vikings (who also seem to have targeted the Balearics in 869), the Emir 'Abd-al Rahmān II (r. 822-852) found the time and resources to mount an expedition against the archipelago with the deliberate intent of forcing the local inhabitants to pay the tribute. $^{65}$

As in the case of Cyprus, however, the truce-agreement did not sever the political, administrative and religious links between the Balearics and Constantinople. Archaeology and material culture pair with the scanty literary evidence to document this continuous connection. One could mention the Byzantine coins found at the castle of Santueri in Mallorca, dated to between the seventh and the ninth century; numismatic evidence documented from Menorca which demonstrates that both Byzantine copper and gold specimens circulated on that island in the early eighth century; ${ }^{66}$ and indeed, although Byzantine consignments seemed to have drastically reduced in the Balearic archipelago towards that date, "a concentration of finds between Justinian I [r. 527-565] and the second reign of Justinian II [r. 705-711] is also noticeable". ${ }^{67}$ Numismatic evidence tallies with two eighth-century lead seals recently discovered in the Balearics. One of them in particular belonged to one Gordo, archon of Mallorca, and pointed to the existence of a "Byzantine" maritime archontate as established in the islands sometime after the loss of Africa. The archons seem to have lasted until the conquest of the archipelago on the part of the Umayyad Caliphate of Cordoba. It is interesting to notice that the lifespan of the above-mentioned archons seems to be confirmed by the numismatic evidence, as Byzantine coins continued to circulate in the Balearics well into the ninth century without any discernible gap. ${ }^{68}$

Therefore, the lead seals point to the existence of Byzantine archons on the islands and to the role the archipelago continued to play in the administrative, military and ecclesiastical structures of Byzantine power. ${ }^{69}$ This impression is further enhanced by additional specimens of seals recently identified in the castle of Santueri as dating to the seventh/ eighth century. The titles on the seals, dux, hypatos, eparchon and spatharios, refer to administrative or military authorities that most probably sent orders to dependent officials residing in this castle, located on the southern coast of Mallorca. ${ }^{70}$ On the other hand, coins like the gold solidi found in the basilica of Son Fadrinet and dated to the reign of Leo III and Constantine V (r. together 737-739), point to the operating fiscal machinery of the island. ${ }^{71}$ Finally, ceramics, and above all recently documented

\footnotetext{
${ }^{64}$ al-Balādhurī, Kitāb futūh al-buldān, trans. Philip K. Hitti, The Origins of the Islamic State, volumes I-II (New York: Columbia

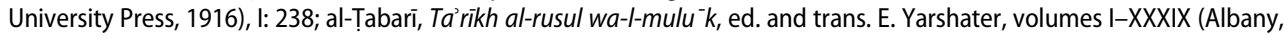
NY: Albany University Press, 1985-2000), VIII: 320-1.

${ }^{65}$ Abū Ibn Idhārī, Kitāb al bayān al-mughrib fi akhbār mulūk al-andalus wa-l-maghrib, trans. A. Huici Miranda, Colección de crónicas árabes de la Reconquista, volumes II-III (Tetuan: Marroquí, 1953-1954), II: 141-4.

${ }^{66}$ Lutz llisch, Michael Matzke and Werner Seibt, Die mittelalterlichen Fundmünzen, Siegel und Gewichte von Santueri, Mallorca [Arbeiten zur Islamischen Numismatik, volume I] (Tübingen: Numismatischer Verlag der Münzgalerie München, 2005), pp. 23-5; Beatrice Moll, "L'Imperi Romà d'Orient a Menorca: El testimoni numismatic", Gaçeta Numismàtica 157 (2005): 5-44.

${ }^{67} \mathrm{Cau}$ and Mas, "Early Byzantine Period", 41.

${ }^{68} \mathrm{lbid}$.

${ }^{69}$ lbid., 40.

${ }^{70}$ Guillermo Rosselló Bordoy, "Nueva luz sobre los siglos oscuros del Baleares y Pitiusas", Bulletí de la Societat Arqueològica Lul.liana 62 (2006): 307-24, p. 316.

${ }^{71}$ Their Ulbert, "El yacimento paleocristiano de Son Fadrinet (Campos, Mallorca)", Mayūrqa 29 (2003): $173-87$.
} 
seventh/eighth-century belt-buckles of Syrian origin, point to the resilient link between the Balearics and the eastern basin of the Mediterranean. ${ }^{72}$

Sigillographic evidence can also help us to assess the rather continuous political, military and perhaps religious links between Sardinia and the Balearics. Indeed, lead- seals belonging to one Georgios apo Eparchon have been found in Mallorca and in Sardinia. They date to the early seventh century and possibly hint at the supervision of state workshops, like the seventh-century dies documented in the little islet of Cabrera. ${ }^{73}$ Vallejo Girvés and Signes Codoñer have indeed cogently shown that the Balearics depended on the Dux Sardinia in administrative terms, especially after the fall of Byzantine Spain in the late seventh century and the conquest of North Africa by the Arabs in the early eighth century. ${ }^{74}$ Moreover, and leaving aside the importance of Mediterranean currents in orienting western Mediterranean shipping routes, ${ }^{75}$ one should also consider the role played by a local detachment of the Byzantine fleet based in Sardinia vis-à-vis the Arab raids that harassed the western Tyrrhenian over the first half of the eighth century. ${ }^{76}$ We can see it in action in 813 when it annihilated an Aghlabid fleet of more than 100 ships that had just raided the island; this battle immediately followed the successful ambush set up by the count of Ampurias Irmingarius against the Arab raiders returning to Spain (via Mallorca) after pillaging Corsica in $812 .{ }^{77}$ The Sardinian fleet also stormed the Arab pirate nest of Fraxinetum in the early tenth century. ${ }^{78}$

Finally, in the almost complete absence of material evidence, Signes Codoñer has demonstrated that chaffing ware yielded in Mallorca was made in the eastern Mediterranean. Indeed, the vessel in question seems to have reached the Balearics via Sardinia. ${ }^{79}$ The latter island also remained the ecclesiastical gravitational pole for the Balearic religious authority: this is enhanced by the famous petitions of the bishop of Gerona, Servusdei, dated to the last decade of the ninth century. The Spanish prelate repeatedly tried to force the Roman papacy to recognise his supremacy over the Balearic archipelago - a request always rebuffed by Rome as the three bishops of Mallorca, Menorca and Ibiza had been regarded as dependent on the Metropolitan of Sardinia since the Synod of Carthage in $484 .^{80}$

Urban excavations as well as surveys of the rural landscape (albeit mostly centred on the numerous fifth-century basilicas) have also shed archaeological light on the period under scrutiny. In the case of urban investigations, the Roman city of Pollentia (modern Alcudia) in the north-eastern corner of Mallorca, has yielded Byzantine

\footnotetext{
${ }^{72}$ Joan C. de Nicolás Mascaró, Connexions síries: Guarniment d'un fernall de cinturó bizantí de tipus "Palmira" de sa Torrevella, Ciutadella (Segle VII) [Arqueomenorca: Monografies, volume XVII] (Maó: Joan C. de Nicolas Mascaró, 2017).

${ }^{73}$ Isabel Busquets Porcel, Josè Rosselló Esteve and Pau Marimon Ribas, "Continuity and Discontinuity in the Balearics Islands during the Byzantine Period (IV-VIII centuries)", unpublished paper presented at the Edinburgh University Seventh Century Colloquium, May 2013.

${ }^{74}$ Vallejo, Hispania y Bizancio, 469-72; Signes, "Bizanci y las islas Baleares", 15-16.

${ }^{75}$ lana Sanna and Lorenzo Soro, "Nel Mare della Sardegna centro meridionale fra 700 e 1100 d.C: Un contrbuto dalla ricerca archaeologica subacquea", in Settecento-Millecento Storia, Archeologia e Arte nei "secoli bui" del Mediterraneo Dalle fonti scritte, archeologiche ed artistiche alla ricostruzione della vicenda storica. La Sardegna laboratorio di esperienze culturali , Atti I, ed. Rosanna Martorelli (Cagliari: Scuola Sarda Editrice, 2013), pp. 767-75: from Gibraltar, along the eastern Spanish coast, towards the Balearics to reach the western coast of Sardinia.

${ }^{76}$ Picard, La mer des califes, 243-49; McCormick, Origins, 510.

${ }^{77}$ Annales Regni Francorum, 137-9; also McCormick, Origins, 900.

${ }^{78}$ Salvatore Cosentino, "Re-Analyzing some Byzantine Bullae from Sardinia", in Siegel und Siegler: Akten des 8. Internationalen Symposions für Byzantinische Sigillographie, ed. Carl Ludwig et al. (Frankfurt-Berlin: P. Lang, 2002) p. 76.

${ }^{79}$ Signes, "Bizancio y las islas Baleares", 20.

${ }^{80}$ Vallejo, Hispania y Bizancio, 443-4; Signes, "Bizancio y las islas Baleares", 52-3.
} 
cooking wares and coins dated to the mid-seventh century (Constans II's reign) and, more importantly, a fortification reusing part of the Forum, is particularly significant. ${ }^{81}$ It seems possible that the city remained frequented in some of its extra-mural quarters until the Umayyad conquest in the tenth century and even beyond. ${ }^{82}$ We should stress, however, that, apart from the results of the excavations at Pollentia, urban archaeology in the Balearics is still in its infancy and other sites such as Palma, Citadela de Menorca, Magona and Ibiza have barely been investigated, leaving much to speculation. ${ }^{83}$

The outlook is more positive if one focuses on the results of a large number of rural surveys run on the archipelago. These have been mainly focused on the fifth-to-sixthcentury basilicas, which dotted the archipelago in a way that recalls the fifty-plus ecclesiastical buildings scattered across the island of Cyprus. There is no space here to present the reader with a detailed overview of the surveys, but of particular relevance here is the one centred on the Basilica of Son Peretó, in the middle of the large Mallorcan plain. The basilica seems to have been refurbished in the late sixth to early seventh century, although it was largely converted into a necropolis in the last decades of the same century. ${ }^{84}$

It is interesting to note that some of the ecclesiastical buildings played an essential role in the settlement pattern of the countryside on the Balearics, as they seem often to have served the purpose of agglutinating local settlements. As Mas and Cau conclude, "although the reduction of site numbers is clear, the settlement patterns do not seem profoundly modified [...] There is no evidence of an extensive flight to the hills" ${ }^{85}$ A further example of this peculiar settlement pattern can be found in the southern part of the island of Menorca, in the territory of Sant Lluís. Here, notwithstanding the absence of early Christian basilicas, metal objects found in various sites in the area point to the continuous presence of settlement and people until the late ninth century with a possible military connotation to some of the inhabited sites, including those located both on the hinterland and along the coast. ${ }^{86}$

With this in mind, it also interesting to note that archaeology and material evidence can be used to dispel the traditional historiographical narrative concerning the fate of the Balearics in the period under scrutiny. This narrative has some interesting parallels with the aforementioned one that described Cyprus as a semi-independent iconophile bulwark. Indeed, as Spanish historiography has often seen the Arab invasion of Iberia in 711 and its impact as an element of change, historians of the Balearics have interpreted the first recorded Arab raid against the islands dated to 707 as ushering the archipelago into a similar semi-independence, predicated upon the loss of Constantinopolitan interest

\footnotetext{
${ }^{81}$ Mateu Riera Rullan, Margarita Orfila and Miguel Cau, "Els últims segles de Pollentia", Bulletí de la Societat Arqueològica Lul.liana 55 (1999): 335-46.

${ }^{82}$ Ibid., 344.

${ }^{83}$ Margarita Orfila, Historia de las Islas Baleares (Madrid: el Mundo, 2006), pp. 224-30.

${ }^{84}$ See Catalina Mas Florit and Miguel Ángel Cau, "Christians and Peasants and Shepherds: The Transformation of Countryside in Late Antique Mallorca (Balearic Islands, Spain)", Antiquité Tardive 21 (2013): 217-32.

${ }^{85}$ Catalina Mas Florit and Miguel Ángel-Cau, "Rural Settlement in Late Antique Mallorca (Balearic Islands): An Interim Approach", Archeologia Medievale 34 (2007): 171-80; Cau and Mas, "Early Byzantine Period"; Catalina Mas Florit and Miguel Ángel-Cau, "From Roman to Byzantine: The Rural Occupation of Eastern Mallorca (Balearic Islands)", Journal of Mediterranean Archaeology 24/2 (2011): 191-217, p. 210.

${ }^{86}$ Joan C. de Nicolás Mascarò, Arqueologia romana del territori de Sant Lluis (Menorca) [Arqueomenorca: Monografies, volume XXXVI] (Maó: Joan C. de Nicolás Mascaró, 2017).
} 
in the western Mediterranean. ${ }^{87}$ Indeed, the Arab source mentioning this attack records the presence of two mulük (kings), who have been regarded as a local governors of the archipelago. $^{88}$

The commander of the Arab fleet was Abd Allah son of that Musa Ibn Nusayr who would have converted soon after the Arab conquest of the peninsula [...] Not only did Abd Allah conquer Mallorca but he also took prisoners, among whom there were the "kings" of Mallorca and Menorca, whom Musa brought to Damascus where they signed a pact sanctioning the subjection of the islands to the Caliph. ${ }^{89}$

However, Rosselló and Signes have persuasively used new archaeological evidence from the island to argue that the mulūk were local representatives of the Byzantine government on the islands, who did not leave the Balearics despite the Islamic presence. ${ }^{90}$

Notwithstanding the continuing presence of Byzantine officials, in the Balearics we can also find traces of a sort of adaptation of the insular structures of governance due to proximity to the Spanish Umayyad Emirate and later the Caliphate, as shown by the 798 Balearic petition for aid to the Carolingian ruler Charlemagne (r. 768814) discussed below, which brought the Frankish fleet to fight and defeat Muslim forces in Mallorcan waters. This is not to imply that similar episodes cannot be traced elsewhere (such as Sardinia, where the local inhabitants likewise appealed to the Carolingian fleet for help against Andalusian pirates in 815); ${ }^{91}$ but rather to stress that the geo-strategic location of the Balearics and Cyprus was both an advantage and a problem, as they experienced the gravitational pull of two massive Mediterranean polities, the Empire and the Caliphate (with occasional third parties like the Carolingians intruding into the picture).

On the one hand, tensions and wars could indeed arise: one could think here of the repeated episodes of forced transplantation of populations in Cyprus, as well as Arab raids (like the one staged in 806 by Hārūn al-Rashīd) or military confrontations, which occurred between the late seventh and the ninth century. ${ }^{92}$ The same could be said for the Balearics, which were repeatedly targeted by Andalusī sea-raiders, who were also responsible for numerous attacks against Sardinia and the southern coast of France between 708 and $903 .{ }^{93}$ One can even mention here the Andalusi pirates who attacked and conquered Crete (via Alexandria) in 821-823. ${ }^{94}$ Before storming the eastern Mediterranean, the pirates plagued the western basin of the Great Sea and in the year 798 the Royal Frankish Annals record a raid of Mauri and Saracens targeting the Balearics, which were

\footnotetext{
${ }^{87}$ See for instance Josep Amengual i Batlle, Els origens del Cristianisme a les Balears I el su desenvolupament fins a l'època musulmana (Palma de Mallorca: Moll, 1991); Miquel Barcelò, "Comentaris a un text sobre Mallorca del geògraf al-Zuhri (s. VI/XII)", Mayūrqa 14 (1975): 155-64, contra Rosselló, "Nueva luz," and Signes, "Bizancio y las islas Baleares".

${ }^{88}$ On the mulūk, see Vallejo, Hispania y Bizancio, 470-5, with further bibliography.

${ }^{89}$ Signes, "Bizancio y las islas Baleares", 2-3.

${ }^{90}$ Rosselló, "Nueva luz", 316; also Signes, "Bizancio y las islas Baleares", 2-4, though cf. Jarrett, "Nests of Pirates".

${ }^{91}$ Royal Frankish Annals, ed. Georg Heinrich Pertz, "Annales Laurissenses et Einhardi", in Monumenta Germaniae Historica [Monumenta Germaniae Historica, Scriptores in folio, volume I] (Hannover: Hahn, 1826), pp. 124-218, esp. 143.

${ }^{92} \mathrm{See}$ on this Piero Fois, "II ruolo della Sardegna nella conquista islamica dell'occidente (VIII secolo)", Rivista dell'Istituto di Storia dell'Europa Mediterranea 7 (2011): 5-26, with further bibliography.

${ }^{93}$ Picard, La mer des califes, 298-311; Jeffreys and Pryor, The Age of the $\Delta \rho \mu \mu \omega v, 33-43$.

${ }^{94}$ Demetrios Tsougarakis, Byzantine Crete from the $5^{\text {th }}$ Century to the Venetian Conquest (Herakleion: Historical Publications St. D. Basilopoulos, 1988), pp. 30-41; Juan Signes Codoñer, "Bizancio y al-Andalus en los siglos IX y X", in Bizancio y la Península Ibérica de la Antigüedad Tardía a l'Edad Moderna, ed. Inmaculada Pérez Martín and Pedro Baldenas de la Peña (Madrid: Consejo Superior de Investigaciones Científicas, 2004), pp. 177-245, esp. 186-99.
} 
therefore forced to call on the Carolingians for defence. ${ }^{95}$ A similar instance occurred in Sardinia, which was hit by a series of Andalusī raids, culminating in 752/3 when the military leader 'Abd al-Rahmān ibn Habīb sacked the island and forced the local inhabitants to pay the jizya; ${ }^{96}$ the Arab chronicler Ibn al-Athīr asserts that after this episode the islands remained unmolested and still populated by the $R \bar{u} m .^{97}$

On the other hand, peculiar socio-political relationships and cross-cultural interactions could take place and produce cultural broker figures like the eighth-century Cypriot Phaggoumenes and the tenth-century bishop Demetrianos (the first referred to by Emperor Constantine VII Porphyrogenitus (r. 913-959), the second the subject of a local hagiography), who could serve as part of embassies which the Byzantines sent to the caliph; or Abū 'Uthmān al-Jazzār, the Ibizenco doctor in charge of the translation of a Greek manuscript sent as a gift to Caliph 'Abd al-Rahmān III (r. 912-961) by the same Constantine VII in 949-952. ${ }^{98}$ Although the Ibizenco doctor could not have been educated on the island, he represents the only available evidence related to socio-cultural life in the early medieval archipelago. Nevertheless, his Balearic origin chimes with an almost contemporary passage in the Glossario de Ripoll. ${ }^{99}$ The latter manuscript dates to the tenth/eleventh century and mentions the Balearics as located "iuxta Hispaniam, ubi pars graecorum est". As the Byzantine rule over the archipelago (whatever its type and intensity) was long gone by then, the Glossario seems to have preserved the memory of the distant sovereignty and cultural influence of the Byzantines over the islands. ${ }^{100}$

It seems possible to surmise that islands in general were ideal laboratories where, out of expediency and necessity, states and local players were engaged in an ongoing process of exchange and blending of cultural elements, to a degree that would not have been acceptable or necessary closer to the hubs of imperial or caliphal power, but which could produce practices, people and places of wider use to these major political actors. In this light, it should come as no surprise that the areas located farther away from Constantinople or closer to alternative sources of political, social and cultural legitimacy (such as the Balearics, Cyprus and even Malta) experimented with new ways of turning the bilateral relationships, whose abutting peripheries they inhabited, into multilateral socio-political tactics geared towards the survival and prosperity of local centres. This in turn created fertile ground for the creation and expression of new identities, carried by such brokers (mainly but not exclusively local elites) beyond ethnic or

\footnotetext{
${ }^{95}$ Signes, "Bizancio y las islas Baleares", 32. This episode seems to run counter to the hypothesis that the islands themselves became a sort of temporary base for pirate activities; although this remains possible, one should also consider that no pirate raids are explicitly mentioned by the sources as setting sail from the archipelago. Indeed, one should also note that "in 848 the Emir of Cordoba sent a fleet against Mallorca to compel the islanders to refrain from damaging Muslim ships passing through their waters" en route to Sardinia or Corsica (McCormick, Origins, 540); this seems to point to local "seabandits" rather than organised sea-raiders.

${ }^{96}$ Maria Grazia Stasolla, "La Sardegna nelle fonti arabe", in Ai confini dell'impero: Storia, arte e archeologia della Sardegna bizantina, ed. Paola Corrias and Salvatore Cosentino (Cagliari: M\&T Sardegna, 2002), pp. 79-92.

${ }^{97}$ 'Alī Ibn al-Athìr, Al-kāmil fi l-ta'rïkh, IV.1. quoted and translated in Stasolla, "La Sardegna", 87-8.

${ }^{98}$ Constantine Porphyrogenitus, De Administrando Imperio, ed. Gy. Moravcsik, trans. R.J.H. Jenkins, Constantine Porphyrogenitus: De Administrando Imperio, 2nd edn [Dumbarton Oaks Texts, volume I] (Washington DC: Dumbarton Oaks Center for Byzantine Studies, 1967, repr. 1993), pp. 224-5; Life of Saint Demetrianos, ed. H. Grégoire, "St. Démetrianos, èvêque de Chytri (île de Chypre)", Byzantinische Zeitschrift 16 (1907): 209-312, pp. 232-3; on the Ibizenco doctor, see Juan Vernet, "Los médicos andaluces en el 'Libro de las generaciones de médicos' de Ibn Yulyul", Anuario de Estudios Medievales 5 (1968): 445-62, p. 448; Signes, "Bizancio y las Islas Baleares", 30-2.

${ }^{99}$ Amengual, "Vbi pars graecorum est," 88; Signes, "Bizancio y las Islas Baleares", 52.

${ }^{100}$ Vallejo, Hispania y Bizancio, 475.
} 
religious borders. ${ }^{101}$ These liminal figures have been repeatedly described as "actors of cross-cultural exchange", who could be traced in various places across the medieval Mediterranean "frontier", and they may in fact be more visible in those areas that could be defined as "division markers but not as barriers between immiscible regions". ${ }^{102}$

As Holmes has stressed, identities should be understood less as an imposition of boundaries and more as a development of shared beliefs and practices. These were indeed often implemented by locals acting as mediators and cultural brokers due to their multicultural skills which made them unable to fit simply into established patterns of ethnic, cultural or religious identity. ${ }^{103}$ "Exchanges, whether material or human [...] contributed to the construction of social identity. For this reason such exchanges are never neutral and [require] acknowledgment of differences". ${ }^{104}$ It is not by chance that this acknowledgement can be better (but not exclusively) ${ }^{105}$ documented on islands like Cyprus, where in the tenth century Muslims and Christians still shared religious spaces, or the Balearic archipelago, where al-Jazzār was born: it is indeed fascinating, as a glimpse into these island spaces, that after the Balearics were definitively conquered by the Spanish Umayyads in 903 and forever lost by Constantinople, an emperor and a caliph could meet virtually through the linguistic talents of a Muslim islander of a former Byzantine land who still spoke the language of the emperors.

To conclude, I have tried to present a reassessment of the important role islands of the eastern and western Mediterranean played within the political and economic structures of the Byzantine Empire in the seventh to tenth centuries. I hope that I have demonstrated that islands were not simply marginal outposts, at best used by the central Constantinopolitan authority as military strongholds or places of exile (like Malta). Islands did not simply belong to the periphery. They were not spaces that can simply be reduced to political or religious utopias (like Cyprus in some representations) or dystopias (like the Balearics or Sardinia), in the imagined view of a Byzantine administration that was supposedly uninterested in the fate of its former possessions in the western Mediterranean. The economic vitality of these islands, the integration of local elites within the Byzantine fiscal machinery, the presence of Constantinopolitan authorities such as archons and the role played by local detachments of the Byzantine navy all contribute to draw a picture of a Byzantine insular system as a socio-economically and politically coherent space.

By pairing this insular system with the other constitutive geo-political pillars of the Byzantine Empire in the early Middle Ages (the Anatolian plateau and the Aegean), I have also been able to posit a second conclusion, stressing another characteristic some islands seemed to share: the capability of local elites to navigate through the ebbs and

\footnotetext{
${ }^{101}$ Athanasios Vionis, "Reading Art and Material Culture", 105.

${ }^{102}$ For a detailed diachronic analysis of medieval cultural brokers, see Acteurs des transferts culturels en Méditerranée médiévale, ed. Rania Abdellatif, Yassir Benhima, Daniel König and Elisabeth Ruchaud [Ateliers des Deutschen Historischen Instituts Paris, volume IX] (München: Oldenbourg, 2012), and especially Nicholas Coureas, "Cultural Brokers at the Court of Lusignan in Cyprus", in ibid., pp. 231-44. Purcell, "On the Significance", 373.

${ }^{103}$ Catherine Holmes, "'Shared Worlds': Religious Identities - A Question of Evidence", in Byzantines, Latins, and Turks in the Eastern Mediterranean World after 1150, ed. Jonathan Harris, Catherine Holmes and Eugenia Russell (Oxford: Oxford University Press, 2013), pp. 31-60.

${ }^{104}$ D. Fairchild Ruggles, "Mothers of a Hybrid Dynasty: Race, Genealogy, and Acculturation in al-Andalus", Journal of Medieval and Early Modern Studies 34/1 (2004): 65-94, p. 87.

${ }^{105}$ See for instance, for the island of Naxos: Athanasios Vionis, "Imperial Impacts, Regional Diversities and Local Responses: Island Identities as Reflected on Byzantine Naxos", in Imperial Lineages and Legacies in the Eastern Mediterranean: Recording the Imprint of Roman, Byzantine and Ottoman Rule, ed. Rhoads Murphey (London: Routledge, 2017), pp. 165-96.
} 
flows of the Mediterranean military, political and religious divide. "Some periods were marked by an intensification of conflicts, more often exchanges and conflict coexisted, and the increase of maritime trade encouraged both competition for control of strategic ports and shipping routes and the search for diplomatic agreements producing trade". ${ }^{106}$ Whether out of convenience, simple political expediency or genuine ability to produce and nurture actors of cross-cultural exchange, islands seem to have exploited their natural inclination to be gateway communities, promoting social encounters and cultural interchange. This apparently passive quality, in other words, clearly vied with the active role played by insular communities in fostering intercultural situations for their own benefit, for as Rainbird states: "those who live with the seas may be regarded as having $[\ldots]$ a willingness [...] to participate in the [...] expectations of continual encounter with otherness, at home or elsewhere". ${ }^{107}$

All the islands or island groups included within the proposed Byzantine "insular system" indubitably moved along similar economic, military and administrative lines (with the partial exception of Sicily), but this closer analysis has allowed the identification of further local nuance and modification of the model; two of them (the Balearics and Cyprus) may be considered spaces where material connectivity and political affiliation with Constantinople seem to have coexisted with intense encounters with new people and the accommodation of social, cultural and political values of their counterparts. ${ }^{108}$ If one agrees that the Middle Ages in the Mediterranean were above all a "moment of the construction of modalities of interactions in shared spaces, of the control and regulation of both exchanges and conflicts", it is also possible to conclude that those who could contribute the most to the "progressive construction for this 'in-between' space" were the inhabitants of places located between barriers and at junctions. ${ }^{109}$ They played (often inadvertently and unconsciously) a role as cultural brokers because their daily life put them in constant contact with political, social and cultural realities imposed directly or indirectly by a close and alternative source to the political and religious legitimisation coming from Constantinople. ${ }^{110}$ The scant and shaky material evidence does not allow more than a glimpse of how this constant interaction transformed into transcultural and transregional political, social and cultural strategies, but permits us to conclude at least that this was integral to the life of those insular thresholds - like Cyprus and the Balearics that took their highly variegated nature from the character of the geo-political zones that impinged upon them and were mediated in a multitude of different ways. ${ }^{111}$

\section{Disclosure statement}

No potential conflict of interest was reported by the authors.

\footnotetext{
${ }^{106}$ Dominique Valérian, "The Medieval Mediterranean", in A Companion to Mediterranean History, ed. Peregrine Horden and Sharon Kinoshita (Chichester: Wiley-Blackwell, 2014), pp. 77-90, esp. 78.

${ }^{107}$ Paul Rainbird, The Archaeology of Islands (Cambridge: Cambridge University Press, 2007), p. 64.

${ }^{108}$ Vionis, "Reading Art and Material Culture", 116-17.

${ }^{109}$ Valérian, "Medieval Mediterranean", 78.

${ }^{110}$ Vionis, "Imperial Impacts", 165.

${ }^{111}$ Purcell, "On the Significance", 381.
} 